\title{
Innovations in the field of state and legal regula- tion of socio-economic activity in Modern times
}

\author{
Gennady Nebratenko ${ }^{1}$, Svetlana Studenikina ${ }^{1}$, and Olga Kazantseva, ${ }^{1, *}$ \\ ${ }^{1}$ Don State Technical University, Gagarin square, 1, Rostov-on-Don, 344003, Russia
}

\begin{abstract}
The proposed article is designed to prove the importance of forming a national economy based on the domestic experience of state and legal regulation, taking into account the realities of the development of international relations, as well as threats arising at the interstate and national levels. At the same time, each state has its own economic system associated with the categories of "economic sovereignty" and "state sovereignty". For that reason, the comparative methodology is reflected in the consideration of the problems stated in the proposed article. The authors proved the importance of financial and economic support of Russia as a social state in order to develop its demographic potential-the most important segment of the national economy construction. In conclusion, the opinion was expressed that ensuring the economic sovereignty of the Russian Federation through the construction of the national economy will have a positive impact on the level of national security.
\end{abstract}

\section{Introduction}

The relevance of the proposed article is determined by the fact that from June 25 to July 1, 2020, a national election was held in Russia to amend the Constitution of the Russian Federation, provided for by the Law of the Russian Federation on amendments to the Constitution of the Russian Federation of 14.03.2020 No. 1-Federal Constitutional Law "On improving the regulation of certain issues of the organization and functioning of public authorities». Of course, the "Constitutional Law Reform - 2020" affects all areas of state and legal regulation, including the economic one, although the priority of modernizing the political and social systems is obvious in the reform, and in the part concerning the economy, more precisely, "political economy", the legislator did not offer drastic solutions, freezing the former rent-and-resource vector of development.

The doctrinal search for solving issues of socio-economic development is determined by the implementation of state-legal reforms approved by the people of the Russian Federation, and the constitutional reform will probably not be the last, since if its provisions are properly executed, there are prerequisites for further constitutional changes that are directly related to the formation of a stable "national economy". The term presented above is taken in quotation marks for the reason that the modern economy is global, in fact, being international, and States that have a self-sufficient economy are considered by the "collective

\footnotetext{
* Corresponding author: kazantseva10@mail.ru
} 
West" as competitors, opponents or outcasts. The present thesis was supported by Alexander Savanovich in his work on economic sovereignty [1]. For that reason, from a liberal point of view, the term "national economy" can be considered a mistake, especially since objectively one of the pillars of economic activity is trade, which has both a national and interstate scale [2] .

Nevertheless, despite the fact that globalization is a network that the Russian Federation is currently a part of, the term national economy is in great demand, since the most important segment of national security is ensuring Russia's sovereignty at the international scene, and sovereignty, in general, can be political, legal and economic, and challenges with ensuring any kind of sovereignty cast doubt on its existence in the state as a whole. Ensuring economic sovereignty is impossible without the availability of its own labor resources in the appropriate amount and their reserve, that is, the national human potential, called in the theory of state and law "population". The presence of the latter is one of the main attributes of the state, and in the theory of national security, it (attribute) is provided primarily due to the impact on the sphere of demographic security.

The doctrinal development of the problems considered in the proposed article is due to the dynamics of economic relations, their unconditional legal support, based on the supremacy of human rights and the actual secondary interests of the state and society, which results in the lack of planning and forecasting for the long-term development of the Russian Federation. As a result of large - scale research in the field of political economy carried out by leading scientific schools, it is almost impossible, since the comparison of economic indicators along the lines of the USSR and the Russian Federation, the countries of Western Europe and North America - the Russian Federation, the States of the Far East-the Russian Federation, will be, to put it mildly, not in favor of the Russian Federation. Futurological forecasts related to forecasts of the development of economic and social indicators also do not have bright prospects. The emergence and wide coverage of statistical data should logically cause their subsequent public explanation, clarification of the causes and those responsible for the economic and industrial "failure", as well as the development of measures to correct the current situation, the key point in the development of which was the "privatisation" of state (people's) property. Therefore, the national experience of state-legal regulation of socio-economic activity in Modern times is considered mainly in the framework of scientific articles from an objective and well-deserved critical point of view. In this respect, we should note the contribution to the Humanities of such scientists as: A. A. Ananyev, M. A. Biganova, O. O. Namlinskaya, L. N. Smirnova, G. G. Kharitonova, Y. F. Shamray, T. A. Shevchenko and many others who are trying to contribute to the improvement of the economic system of the Russian Federation. Among the foreign authors who have paid attention to the issues under study are Prateek Agarwal, Kim, Jinill, Leonore Fleming, Chris Renwick, Yunus Aksoy, Henrique S. Basso, Ron P. Smith, Tobias Grasl, Alexander Savanovic.

\section{Materials and methods}

The technical-legal, system-structural, and comparative special-scientific methods were used in the preparation of the article. The technical legal methodology was expressed in the use of a set of legal acts aimed at regulating relations in the field of the economic system when writing the article. The latter, in the framework of the system-structural method, was considered as an integral substance that has its own organic interdependence.

Specifically, it would be desirable to express gratitude to the residents who supported the amendments to the Constitution of the Russian Federation (the Basic law), as they will create conditions for the rehabilitation of the national economic system. When preparing 
the article, we used sources related to the field of legal practice, primarily constitutional law, as well as economic theory. In addition, the chosen topic has scientific connections with political science. The proposed article differs from works of a similar orientation by using a complex of scientific knowledge accumulated within the framework of the concept of a social system that structurally includes as subsystems: economy, politics, law, industry, education, culture, management. Such an approach in modern conditions seems original and deserves to be applied in practice, since its implementation at the Federal and regional levels is characterized by industry-specific reform, but it occasionally turns out to be ineffective, since objective reality explicates the existence of intersectoral management. Therefore, the proposed article has scientific novelty not only from the subject, but also from the methodological point of view.

Article 75 of the Constitution of the Russian Federation now contains the fifth paragraph: "The Russian Federation respects the work of citizens and ensures the protection of their rights. The government guarantees a minimum wage that is not less than the minimum subsistence amount of the working age population in the Russian Federation as a whole". That is an absolutely correct proposal of the legislator, which is to some extent populist, because based on the principles of common sense, there can be no other way. Instead, the text of the Constitution of the Russian Federation would be more precise in the wording that guarantees the reimbursement of labor "...more than the subsistence minimum", perhaps not less than one and a half or two times. Otherwise, the legislator creates conditions for decrease in labor productivity and development of everyday corruption, since each person has not only physiological needs, they must have a family and children, and it is probably appropriate to work productively at the rate for a "food set" during a war or another test for the people.

However, according to the authors, such a provision is more appropriate to be included as an article (hypothesis and disposition) of the Criminal code, in Chapter 19 "Crimes against the constitutional rights of human and citizen". Wages paid for a full day of a five day working week, in an amount that does not make up the subsistence minimum-this is really a civil injury that requires criminalization. The subject of such a crime can be an official (employer), and it is strange why this provision has not yet appeared in the Criminal code of the Russian Federation, because Russia is declared a social state, where the official level provides for the creation of conditions for ensuring a decent life and free development of a person.

Further, the new edition of the 114 article of the Constitution of the Russian Federation states that the government of the Russian Federation "implements measures aimed at creating favorable living conditions for the population, reducing the negative impact of economic and other activities on the environment, preserving the unique natural and biological diversity of the country, and forming a responsible attitude towards animals in society". Actually, unfavorable living conditions in some cities and localities began to arise even during the existance of the USSR, and it is strange that before "creating favorable living conditions for the population" was not considered as a constitutional task of the government of the Russian Federation. After all, the pollution of nature associated with the activities of industrial enterprises and the cost-cutting of economic entities for the modernization of production is directly related to the health of the population, and, ultimately, to its reproduction and growth.

Recent examples of large-scale environmental violations include the "Arctic disaster" that occurred on 29.05.2020 at the TPP-3 owned by the Norilsk-Taimyr Energy company, which is part of the "Norilsk Nickel" mining-and-metallurgical integrated works (General Director V. O. Potanin). It is likely that now, after the amendment of the Constitution of the Russian Federation, responsibility for improper prevention of environmental disasters, and, 
consequently, offenses of law will be more specific, with the possibility of its attribution to the Federal Executive authorities and direct management of economic entities, and not only civil liability. After all, property is not only a benefit, but also a burden, and the profit received should be partially spent on timely modernization of production, cutting on which, taking into account the socially dangerous consequences that have occurred, should also be criminalized.

Further, in article 131 on local self-government in the Russian Federation, the population as a subject of law is mentioned several times, and even in the first edition of the Constitution (12.12.1993). At the same moment, the article has paragraph 3: "Local selfgovernment bodies and state authorities are part of the unified system of public authority in the Russian Federation and interact to most effectively solve issues in the interests of the population living within the relevant territory». In other words, "the most effective solution of problems in the interests of the population" is considered as the value and purpose of the functioning of the "unified system of public authority in the Russian Federation", which itself, if fully implemented, deserves full approval.

\section{Results}

Thus, the implementation of the new provisions of the Constitution of the Russian Federation makes it possible to create conditions for the formation of a true social state and should contribute to the growth of the population in the Russian Federation, which is directly related to the socio-economic development of the country. Even taking into account the current unemployment rate, the state should have a population of about 200 million people in order to build a national economy that is harmoniously integrated into the world economy (on the example of the people's Republic of China). In the USSR, which developed quite dynamically until the mid-80s of the XX century, especially taking into account the demonstration of modern GDP growth rates in the former Soviet republics, the population was about 293 million people. Therefore, in the "Basic Law - 2020", upgraded taking into account the national amendments, the main amount of changes is aimed at creating conditions for improving the socio-economic climate, however, the term "demography" is not used, while "population" is used 5 times.

Negative balance in the demography that emerged in 2018 (table 1), indicates that previously taken measures aimed at ensuring demographic security are no longer sufficient [3]. From the theoretical aspect, our work is related to the study of the impact of demography on the economy (for example, Yunus Aksoy, Henrique S. Basso, Ron P. Smith, Tobias Grasl, Yana Wobeska, William P. Butz, Herald Cirilo Reyes) [ 4,5].

Table 1. Demographic indicators of Russia

\begin{tabular}{|c|c|c|c|c|c|c|}
\hline \multirow{2}{*}{ Year } & \multicolumn{3}{|c|}{ Total people } & \multicolumn{3}{c|}{ Per 1000 residents } \\
\cline { 2 - 7 } & born & died & natural increase & born & died & $\begin{array}{l}\text { natural } \\
\text { increase }\end{array}$ \\
\hline 2010 & 1788948 & 20208516 & -239568 & 12,5 & 14,2 & $-1,7$ \\
\hline 2011 & 1796629 & 1925720 & -129091 & 12,6 & 13,5 & $-0,9$ \\
\hline 2012 & 1902084 & 1906335 & -4251 & 13,3 & 13,3 & 0,0 \\
\hline 2013 & 1895822 & 1871809 & 24013 & 13,2 & 13,0 & 0,2 \\
\hline 2014 & 1942683 & 1912347 & 30336 & 13,3 & 13,1 & 0,2 \\
\hline 2015 & 1940579 & 1908541 & 32038 & 13,3 & 13,0 & 0,3 \\
\hline 2016 & 1888729 & 1891015 & -2286 & 12,9 & 12,9 & $-0,01$ \\
\hline 2017 & 1690307 & 1826125 & -135818 & 11,5 & 12,4 & $-0,9$ \\
\hline 2018 & 1604344 & 1828910 & -224566 & 10,9 & 12,5 & $-1,6$ \\
\hline 2019 & 1648954 & 1862547 & -213593 & 11,0 & 12,0 & -1 \\
\hline
\end{tabular}


In addition, the population in various regions of the state is asymmetric: it is sharply decreasing in the far East and Siberia; it is decreasing in Central Russia; it is increasing in the North Caucasus Federal district; it is significantly increasing in the federal city of Moscow, but at the expense of migration... These trends pose a threat to the national security of the Russian Federation in the medium term, and their elimination is connected with the need to resolve a number of other contradictions that arose in the post-Soviet period (deindustrialization, corruption, unequal distribution of income between subjects, asymmetry of the state system, lack of a national idea...).

As a result, effective building of the national economy, which is harmoniously integrated into the world economy, is currently problematic, and even increasing the retirement age of citizens of the Russian Federation does not solve the production and demographic problems in any way. To build a competitive sovereign economy, the population of the Russian Federation is expected to grow 1.5 times and be engaged in solving national-scale problems, such as industrialization or collectivization of the national economy in the late $20 \mathrm{~s}-$ 30 s of the XX century, which made it possible to increase resistance to external threats from Germany and Japan, as well as satellites.

The main factors of the country's economic security are its geographical location, natural resources, industrial and economic potential, the degree of socio-demographic development, and the quality of life [6].

Meanwhile, there are no conditions for multiple population growth in Russia yet, primarily for financial and economic reasons, and it is appropriate to analyze the income basis received on the territory of the Russian Federation after the privatization of the 90s of the XX century, and the practice of spending it. In article 3 of the Constitution, the legislator clearly stated that the holder of sovereignty and the only source of authority in the Russian Federation is its multinational people, and therefore all problems associated with its normal functioning automatically affect the level of sovereignty, that is, there are problems of ensuring national security, including in the economic sphere. To break the "demographic stalemate" that directly affects the effectiveness of the state and legal regulation, even unprecedented measures comparable to those used by the government during the great Patriotic war are acceptable. It was then, taking into account the decline in the population at the front and during the occupation, that the state took upon the economic burden of comprehensive support for marriage, family, childhood and motherhood, and did not allow homelessness... Such historical and legal experiences, including those presented in the formal legal dimension, require careful analysis for possible reception [7].

There is also a negative impact of the demographic decline on the economies of States. This conclusion is supported by Ginil Kim and Loretta J. Mester in their articles on the impact of demographic changes on the economy [8,9].

First of all, the scourge of modern Russia is artificial abortion (without medical indications), which is considered by the legislator as a woman's right. However, in domestic and international practice, the prohibition of abortions is not an out-of-the-ordinary phenomenon, it helps to protect the nascent human lives and the health of a future mother. If the latter is in a state of unwanted pregnancy and does not plan to raise a newborn in the future, then the burden of caring for the baby can be borne by society and the state. The latter must do this, as in the 90s of the XX century it allowed a "demographic pitfall" comparable to the indicators observed in 1941-1945. Moreover, many children later find themselves in large foster families (family orphanages) that can compensate for the child the parents' warmth. The objective reality of the functioning of ordinary orphanages in the Russian Federation is not always presentable, including due to insufficient funding of the education- 
al system in the Russian Federation, and most importantly, the fundamental lack of a general spiritual and moral line.

The idea of prohibiting (restricting) abortion will obviously be supported by traditional confessions and met with hostility by the liberal-minded part of society that has direct access to mass media, as well as by foreign partners who dehumanize Russia because of their devotion to traditional family values. Moreover, the Constitution of the Russian Federation now has article 67.1., the 4th paragraph of which declares: "Children are the most important priority of Russian state policy. The government creates conditions that promote the comprehensive spiritual, moral, intellectual and physical development of children, and foster patriotism, citizenship and respect for their elders. The government, ensuring the priority of family education, takes upon the responsibilities of parents in relation to children left without care".

It is necessary to prohibit abortions performed without medical indications, at least for women who do not have their own children, especially underaged ones. It is for them that artificial termination of pregnancy often ends in infertility, and the subsequent joy of motherhood becomes possible only by surrogacy or adoption. However, it is necessary to prohibit (restrict) abortions in the Russian Federation not only for humane reasons, but at least for pragmatic needs, since people are the same "resource" that ensures the sovereignty of the state in times of peace and protects its integrity in times of severe trials. This idea is particularly relevant in the year of the 75th Anniversary of the victory in the Great Patriotic War, and since some foreign partners are trying to deform our role (demonize), while spreading their military infrastructure near the border, the Russian Federation cannot afford "political relaxation" and must seek economic sovereignty, including recognition of the ruble as a reserve currency at least on a regional scale.

Meanwhile, there are various scientific schools in economic theory based on a variable attitude to population growth, to demography as the most important indicator of the dynamics of state development. It should not be also hidden that there are doctrines that are skeptical of population growth, which actually justify the need for forced population decline, for example, the "Malthusian economic school", which to some extent found support in the modern States of the "collective West" [10,11,12]. Fighting population growth, which is impossible after the victory over Nazism by force, is carried out by artificially replacing traditional human values with "illusory" ones, initially carried out by mass communications. Therefore, at present, human infertility is elevated to the level of a natural weal associated with human rights consolidated by law. Early sexual education, the imposition of an alternative choice of social sex (gender), the legalization of homosexuality, the change of biological sex (voluntary castration) have become the pillars of official propaganda, especially among young people.

Therefore, the new edition of the current Constitution of the Russian Federation has been amended to put a barrier to the manifestations of "neo-malthusianism": the family, motherhood, fatherhood and childhood are protected, while marriage is recognized as the Union of a man and a woman? because it is the kind of Union that provides the genesis of humanity. The "Basic Law" creates conditions for preventing an artificial reduction in the population of Russia, whose density is already small, and not only in the Eastern part of the state, but also in Central Russia, excepting, of course, cities.

Based on the above, the misanthropic concepts of the "Malthusian economic school" and "neo-malthusianism", which are formally and legally covered under plausible excuses to ensure human rights, are unacceptable for the Russian Federation, for which population growth is a priority, not a burden. And since the man-hateful nature of malthusianism is obvious and anti-scientific, since science is designed to serve people, and not to sequester humanity, we should pay attention only to neo-malthusianism, which explains the concern 
in the States of the "collective West" for non-traditional minorities, whose legal status becomes almost more predominant than that of most others $[13,11]$.

\section{Conclusion}

Thus, the peculiarity of neo-malthusianism is that it has moved from the exclusive economic sphere of scientific knowledge to political and legal practical activities [9,10]. As a result of the restriction of childbearing, although not proclaimed as an important neo-Darwinian idea, but conditions are formed when representatives of more numerous, but less well-off social groups are unable to reproduce themselves, and the spread of harmful ideas of sexual corruption coexists with the spread of sexually transmitted diseases and infections, drug addiction, AIDS, described for the first time in 1881 by the United States centers for disease control and prevention. At the same time, more humane methods of reducing the birth rate are also used, for example, the popularization of contraception, which goes along with the "marketing" of unbridled sexual manners imposed on young people.

Finally, global events related to the spread of various viral diseases, such as SARS in 2002-2003, swine flu in 2009, and C-type pneumonia in 2019-2020, show that in times of extreme danger, States close their borders and literally survive using the resources of their own economy. In this sense, the Russian Federation has demonstrated its stability, at least in the framework of the "first wave" of Covid-2019, which, oddly enough, was partly the result of the political harassment (discrimination) of the Russian Federation by the "collective West" led by the North American States, organized in 2014, giving rise to import substitution, especially in agriculture.

In conclusion, it should be noted that more than a thousand-year history of state and law allows Russia to use not only foreign, but also national experience of socio-economic development, but perhaps the most harmful phenomenon would be the baseless denial of national experience, since it has already been tested by time, allowing the formation of the world's largest state. The fault-finding attitude towards our Fatherland is derived from foreign detractors who are outraged by the very existence of the Russian state, and this kind of intolerance, or rather Russophobia, has genetic roots, sometimes transmitted from generation to generation, whether the country is called the Russian Empire, the Soviet Union or the Russian Federation. In these difficult geopolitical conditions, the Russian people, the defenders of Russia's sovereign rights in the international arena, are actually being hardened, and the construction of the national economy is designed to create conditions for its natural reproduction on its own territory and solve the most important urgent tasks. In this respect, the doctrine of the "marginalist economic school" is more acceptable [14]. The resoluting issues related to ensuring Russia's economic sovereignty will ensure its political and international legal aspects [15].

The real increment of scientific knowledge that arose during the preparation of the present article, which is not limited to stating the results of the research, consists in the proposal to move from the market economy that is being built in the Russian Federation to a multi-layered one, which provides for the equivalent use of "private economic initiative" and state planning. After all, the experience of the 30-year supremacy of the market economy did not justify itself with the results of the socio-economic development of the state, in contrast to the indicators that were demonstrated in 1945-1985. The justification of the particular result is due to the endless "war" of the Russian government with poverty and pauperism, which in 1991-2021 varies in the range of tens of percent, but does not disappear, although it was not observed at all in the planned-administrative economy among the population. Another concrete result is the conclusion that it is necessary to develop a national social ideology designed for the long term, which would save the Russian Federation from 
implanting harmful destructive political influence among its population, created from outside in order to achieve a very obvious result.

\section{References}

1. A. Savanovic, 12th International Academic Conference, Prague ISBN 978-80-8792704-5 (University of Banja Luka, Bosnia and Herzegovina Economic sovereignty, 2014) http://proceedings.iises.net/index.php?action=proceedingsIndexConference\&id $=7$ (Last accessed 12.06.2020)

2. J.L. Cohen, Columbia University, New York, Publisher: Cambridge University Press, 21-79 DOI: https://doi.org/10.1017/CBO9780511659041.003,

3. Country statistical profile: Rusian Fedetion 2018/1 DOI :https://doi.org/10.1787/csprus-table-2018-1-en.

4. Y. Aksoy, H.S. Basso, R.P. Smith, T. Grasl, American Economic Journal: Macroeconomics, 11(1), 193-222 (2019) DOI: 10.1257 / mac.20170114

5. J.W. William, P. Butz, H.C. Reyes, Population Trends and Policies in the UNECE Region (2013) https://eeca.unfpa.org/sites/default/files/pubpdf/Population\%20Trends\%20and\%20Policies\%20in\%20the\%20UNECE\%20Region $\% 20 \% 28$ Russian\%29_0.PDF (Last accessed 18.06.2020)

6. E. Grigoreva, L. Garifova, Procedia Economics and Finance 24, 266 - 273 ( 2015 ) doi: 10.1016/S2212-5671(15)00658-9

7. G. Nebratenko, S. Studenikina, O. Kazantseva, T. Moskaleva, SHS Web of Conferences The conference proceedings, 11007 (Don State Technical Universyty, 2019)

8. K. Jinill, Washington: Board of Governors of the Federal Reserve System, September 28 (2016) https://doi.org/10.17016/2573-2129.22

9. L.J. Mester, Cato Institute's 35th Annual Monetary Conference: The Future of Monetary Policy Washington ( 2017) https://www.clevelandfed.org/en/newsroom-andevents/speeches/sp-20171116-demographics-and-their-implications-for-the-economyand-policy.aspx (Last accessed 12.06.2020)

10. P. Agarwal, Development Economics (2020)

11. R.M. Ebeling, The future of freedom foundation (2017) https://www.fff.org/explorefreedom/article/economic-ideas-thomas-malthus-population-passions-property-politics/ (Last accessed 12.06.2020)

12. F. Estenssoro, D. Humanos, Relacoes Internacionais y Meio Ambiente. Curitiba, Multimedia Editora, 217-238 (2013)

13. T.K. Birch, Growth Limits Revised, Canadian population research 43(1-2), 160 (2016) doi: 10.25336/P6K89F.

14. S. Metelev, M.M. Murat, V. Lizunov, Economic Security Policy of the Russian Federation, Rangendingen, (2016)

15. E. Rudakova, B. Sangadzhiev, N. Eriashvili, V. Gushchin, M. Zhukova, Revista Espacios,

41, 24

https://www.revistaespacios.com/a20v41n07/a20v41n07p24.pdf 19.06.2020)
(2020)

(Last accessed 